\author{
A.A. Kassymzhanova ${ }^{1}\left(\mathbb{D}\right.$, Pierre Tifine $^{2}(\mathbb{D}$, \\ G.R. Usseinova ${ }^{1}$, A.S. Ibrayeva ${ }^{1}$, D.A. Tursunkulova ${ }^{1}{ }^{(\mathbb{D}}$ \\ ${ }^{1}$ Al-Farabi Kazakh National University, Kazakhstan, Almaty \\ e-mail: Ainur.kassymzhan@gmail.com; gulnara_usein@mail.ru; ibraeva_tgp@mail.ru; adilek03@mail.ru \\ ${ }^{2}$ Institute of Research of Nation and State Evolution (IRENEE) of the University of Lorraine, \\ Université de Lorraine, France, Metz, e-mail: pierre.tifine@univ-lorraine.fr
}

\title{
STATE AND LEGAL BASIS FOR ENSURING OF EXTERNAL SECURITY OF THE REPUBLIC OF KAZAKHSTAN
}

This article is devoted to the legal analysis of external security of the Republic of Kazakhstan. It also explores various approaches to the study of external security in accordance with the Kazakh legislation and legal standards of foreign countries. The article considers the scientific positions of scientists that they set out in the process of conducting fundamental research. Currently, the Republic of Kazakhstan has a fairly extensive security system. This article is devoted to the legal analysis of the state's activities in the field of external security. There are both theoretical and practical problems in this area. Ensuring external security requires a special approach to the legal regulation of this sphere. Thus, a single conceptual framework has not yet been developed. It should also be noted that the issues of administrativelegal regime need to be solved through which in fact a degree of ordering has achieved as the system of external security and its components and individual processes in the field of security of individuals, society and the state.

Key words: national security, ensuring security, external security, the Constitution, law, threats to external security.

\author{
А.А. Касымжанова ${ }^{1}$, Пьер Тифини ${ }^{2}$, \\ Г.Р. Усеинова ${ }^{1}$, А.С. Ибраева ${ }^{1}$, А.А. Турсынкулова ${ }^{1}$ \\ 'Ә^-Фараби атындағы Қазақ Ұлттық Университеті, Қазақстан, Алматы \\ e-mail: Ainur.kassymzhan@gmail.com; gulnara_usein@mail.ru; ibraeva_tgp@mail.ru; adilek03@mail.ru \\ ${ }^{2} \wedge$ отарингия университеті (IRENEE) ұлт және мемлекет эволюциясын зерттеу институты, \\ Аорейн Университеті, Франция, Мец к., е-mail: pierre.tifine@univ-lorraine.fr
}

\section{Қазақстан Республикасының сыртқы қауіпсіздігін қамтамасыз етудің мемлекеттік-құқықтық негіздері}

Бұл мақала Қазақстан Республикасында сыртқы қауіпсіздікті қамтамасыз ету мәселелерін құқықтық талдауға арналған. Сонымен қатар, бұл жұмыста қазақстандық заңнамаға және шет мемлекеттердің құқықтық стандарттарына сәйкес сыртқы қауіпсіздікті зерттеудің түрлі тәсілдері зерттеледі. Іргелі зерттеулер жүргізу барысында ғалымдардың ғылыми ұстанымдары қарастырылады. Қазіргі уақытта Қазақстан Республикасында қауіпсіздікті қамтамасыз етудің жеткілікті түрде тармақталған жүйесі қалыптасты. Бұл мақала сыртқы қауіпсіздікті қамтамасыз ету саласындағы мемлекеттің қызметіне құқықтық та^дау жасайды. Бұл салада әлі де шешімін таппаған теориялық және практикалық мәселелер бар. Сыртқы қауіпсіздікті қамтамасыз ету осы саланы құқықтық реттеуге ерекше көзқарасты талап етеді. Осылайша, әлі күнге дейін бірыңғай түсінік аппараты әзірленбеген. Сондай-ақ, іс жүзінде сыртқы қауіпсіздік жүйесі мен оның компоненттерінің, сондай-ақ жеке адамның, қоғам мен мемлекеттің қауіпсіздігін қамтамасыз ету саласындағы жекелеген процестерді ретке келтірудің тиісті дәрежесіне қол жеткізілетін әкімшілік-құқықтық, режим мәселелері де өз шешімін талап ететінін атап өткен жөн.

Түйін сөздер: ұлттық қауіпсіздік, қауіпсіздікті қамтамасыз ету, сыртқы қауіпсіздік, Конституция, сыртқы қауіпсіздікке оқталу. 


\author{
А.А. Касымжанова1, Пьер Тифини², \\ Г.Р. Усеинова ${ }^{1}$, А.С. Ибраева ${ }^{1}$, А.А. Турсынкулова \\ ${ }^{1}$ Казахский национальный университет имени аль-Фараби, Казахстан, Алматы \\ e-mail: Ainur.kassymzhan@gmail.com; gulnara usein@mail.ru; ibraeva tgp@mail.ru; adilek03@mail.ru \\ 2 Институт исследований эволюции нации и государства (IRENEE) университета Аотарингии, \\ Университет Аорейн, Франция, г. Мец., e-mail: pierre.tifine@univ-lorraine.fr
}

\title{
Государственно-правовые основы обеспечения внешней безопасности Республики Казахстан
}

\begin{abstract}
Аанная статья посвящена правовому анализу обеспечения внешней безопасности Республики Казахстан. В ней также исследуются различные подходы к исследованию внешней безопасности в соответствии с казахстанским законодательством и правовыми стандартами зарубежных государств. Рассматриваются научные позиции ученых, из^оженные ими в процессе проведения фундаментальных исследований. В настоящее время в Республике Казахстан сформирована Аостаточно разветвленная система обеспечения безопасности. Аанная статья посвящена правовому анализу деятельности государства в области обеспечения внешней безопасности. В Аанной области имеются как теоретические, так и практические проблемы. Обеспечение внешней безопасности требует особого подхода к правовому регулированию данной сферы. Так, до сих пор не выработан единый понятийный аппарат. Также следует отметить, что требуют своего решения вопросы административно-правового режима, посреАством которых в Аействительности Аостигается должная степень упорядоченности как самой системы внешней безопасности и ее составляющих, так и отдельных процессов в области обеспечения безопасности мичности, общества и государства.
\end{abstract}

Ключевые слова: Национальная безопасность, обеспечение безопасности, внешняя безопасность, Конституция, закон, угрозы внешней безопасности.

\section{Introduction}

Ensuring external security is one of the pressing problems of our time. Not a single state in the world currently considers the issue of external security to be legally resolved. The Republic of Kazakhstan is no exception. The term "external security" appeared in political science relatively recently, in the second half of the 20th century after the adoption of the Law on National Security in the USA in 1947. In the Republic of Kazakhstan, the legal act that laid the foundation for theoretical and practical activities in the field of ensuring external security is the Law "On National Security of the Republic of Kazakhstan" dated June 26, 1998. For the first time, the concept of external security was introduced at the legislative level in this law. So, external security was understood as the state of protection of the national interests of the Republic of Kazakhstan from threats posed by foreign states, organizations and citizens (https://online.zakon.kz/document).

In the current law of the Republic of Kazakhstan "On the National Security of the Republic of Kazakhstan" adopted on January 6, 2012, the concept of external security is absent (https://online. zakon.kz/document).

External security is a complex multi-level functional system in which processes of interaction between the vital interests of the individual, society and the state continuously occur. These interests are a set of needs, the satisfaction of which reliably ensures progressive social development. Hegel wrote that lack of interest is spiritual or physical death.

The Republic of Kazakhstan in accordance with national legislation and international treaties ensures the safety of every person and citizen on its territory. Citizens of Kazakhstan, as well as legal entities located outside the Republic of Kazakhstan, are guaranteed by the state the protection of their personal, family and business interests abroad. These standards are laid down in the Foreign Policy Concept of the Republic of Kazakhstan for 2014-2020, developed in accordance with the guidelines set forth in the Message of the President of the Republic of Kazakhstan to the people of Kazakhstan, "Kazakhstan Strategy-2050: a new political course for a successful state." The Concept notes that, taking into account modern realities, the foreign policy of the Republic of Kazakhstan requires modernization and promotion of national interests on the principles of pragmatism. This process is influenced by a number of internal and external factors. Among external factors, the need for overcoming the negative consequences of the global financial and economic crisis, aggravation of conflicts and modern problems of mankind, the emergence of a qualitatively new geopolitical and 
geoeconomic situation at the regional and global levels is indicated.

According to Art. 39 of the Constitution of the Republic of Kazakhstan, while ensuring the safety of the rights and freedoms of man and citizen, may be limited only by laws and only to the extent necessary to protect the constitutional order, protect public order, human rights and freedoms, health and morality of the population (https://online.zakon.kz/ document).

In this case, any person, in the manner prescribed by law, is entitled to receive clarifications from the relevant state bodies regarding the restriction of their rights and freedoms. Officials who have exceeded their authority in ensuring security shall bear the responsibility established by law.

The state guarantees support to persons providing assistance in ensuring national security, including their legal protection in accordance with the legislation of the Republic of Kazakhstan. The Republic of Kazakhstan ensures the safety of every person and citizen on its territory. Citizens of Kazakhstan who are outside the Republic of Kazakhstan are guaranteed protection and patronage by the state. The Republic of Kazakhstan ensures its national security by all means and methods at its disposal. Note the diversity of these methods. These are economic, political, military, legal. Special methods are used by special bodies - intelligence, counterintelligence (https://online.zakon.kz/document).

In order to obtain international security guarantees, the Republic of Kazakhstan is involved in ensuring international (global, regional) security, of which the national security of Kazakhstan is an integral part. The activities of the Republic of Kazakhstan to ensure international security include:

1) strengthening the role of Kazakhstan in the formation of the global world order;

2) the formation and strengthening of an effective collective security system in the geopolitical environment of Kazakhstan;

3) participation in international organizations and forums whose activities are in the interests of the national security of the Republic of Kazakhstan;

4) participation outside the country in activities aimed at ensuring national security in accordance with international treaties of the Republic of Kazakhstan;

5) the decision, if necessary, in conjunction with neighboring countries, issues related to national security;

6) the conclusion of international treaties that meet the security interests of the Republic of Kazakhstan.

\section{Main part}

For any state, the issue of ensuring national security and protecting national interests in international relations is one of the strategic issues in developing the country's foreign policy. This is the manifestation and realization of the sovereignty of the state, which implies its right to act as an independent subject of international relations, to determine foreign policy in its interests and to independently resolve issues of foreign economic activity.

It is no secret to anyone that in the modern world there are security threats related to the targeted impact on economic and military potential, social development, information space, ecology and other areas of the state's activity.

In matters of ensuring national security, an important component is the foreign policy of the state. Realizing its foreign policy functions, each state pursues a certain policy outside its country, i.e. in international relations. The theory of "geopolitics" has developed in the theory of international relations, which is an organic relationship between spatial relations and the historical causality of state actions. The theory of "geopolitics" is based on such values as "sovereignty", "territory", and "state security". The geopolitical position of the Republic of Kazakhstan largely determines the priorities for the implementation of external security.

External security of the state is a system of measures aimed at establishing and maintaining relations with subjects of international law, protecting national security and interests, as well as expanding its influence on other subjects of international relations. External security includes the foreign policy of the state, foreign policy doctrines, concepts, bodies that carry out foreign policy functions, and most importantly - the foreign policy of the state.

External security is realized through diplomacy, direct and indirect, which, in turn, must comply with international law. At the same time, international law has a direct impact on state policy in the field of external security through the fact that states must comply with their international obligations. Both diplomacy and external security should not conflict with universally recognized principles and norms of international law. The general nature of diplomacy is largely determined by the socio-economic development of the state, as well as by the general laws and rules governing international relations as a whole. As for the role of diplomacy in international law, diplomacy, formulating the will of the state and 
seeking its agreement with the will of other states, actively participates in the creation of international law, is an extremely important factor in law-making in international relations.

The effectiveness of diplomacy, as a rule, depends on how the goals and objectives of the state's policy in the field of external security are formulated, as well as how successfully they are implemented in practice by specific individuals.

Foreign policy directly depends on the domestic political, economic, demographic, military, scientific, technical, cultural potential of the state. Depending on the state's potential, certain priorities in external security are taking shape. The main form of implementing external security is the establishment of diplomatic relations between states, membership in international organizations and, accordingly, the opening of permanent missions of states to international organizations. Active foreign policy activities of the state, the presence of stable relations with other subjects of international law enable the state to apply various means and methods, combine them, carry out regular exchanges of information, visits at different levels, conclude agreements on various issues, create and join blocks and unions in various areas of cooperation.

The determination of foreign security priorities is influenced by such factors as the level of sociopolitical, socio-economic development, the geopolitical position of the country, as well as the presence of certain national interests, which together comprise the system of ensuring national security of the Republic of Kazakhstan.

In clause 6 , article 1 of the Law on National Security, the national interests of the Republic of Kazakhstan are understood as the totality of legislatively recognized political, economic, social and other needs of the Republic of Kazakhstan, the implementation of which determines the ability of the state to protect human rights and citizen values of Kazakhstan society and the foundations of the constitutional system. As a result, the national interests are ensured by the state by all means at its disposal-economic, political, ideological, diplomatic, military, etc.

The concept of "national security" is closely related to the concept of "national interest." National security is considered as one of the elements of the national interest of the state, which ensures, along with other elements (internal stability, economic prosperity, favorable external environment, positive international image), optimal existence (Baykenzheev 2017: 198).
It should be noted that the main determining national interest of any state is the "instinct of selfpreservation", which includes ensuring national security from external threats, protecting the economic and political positions of the state in the world, a certain impact on the foreign policy of another state, as well as the expansion of the influence of the state on world politics as a whole.

When realizing their national interests, the behavior of states can be classified into four types:

- aggressive policy - manifests itself in the desire to expand its influence and resolve internal problems by means of foreign policy;

- conservative politics - a kind characteristic of the former "great" states, empires, which is based on the desire to maintain its influence in the international arena and previously achieved position without taking into account the changed alignment of forces and real potential;

- active policy - based on a balance between the internal and external activities of the state, when it as a whole successfully acts as a subject of international relations, protecting its interests;

- passive policy - is characteristic of "weak" states, which do not have the potential necessary to assert their sovereignty, therefore they are forced to give up part of their sovereignty for the sake of more "strong" neighbors or patrons (Mansurov 2011).

The study of foreign policy of Kazakhstan characterizes the Republic of Kazakhstan as a state with an active and balanced domestic and foreign policy. Regarding the balance of the state's policy as a whole, the President of Kazakhstan, KasymZhomart Kemelovich Tokaev, notes: "The close relationship between Kazakhstan's foreign and domestic policy is determined by the unity of purpose - building a democratic society with a socially oriented market economy and guaranteed protection of the constitutional rights of citizens of the country. The foreign policy of the Republic of Kazakhstan is characterized by such qualities as balance and multi-vectority, which suggest pragmatism in the choice of foreign policy partners, a high degree of maneuverability, the absence of a direct dependence of Kazakhstan's foreign policy on the unpredictability of the development of a situation in a particular region, on changing world market conditions" (Tokayev 1998a: 12).

The external security of our country initially proceeded from the need to uphold long-term national interests by means of broad international cooperation and solving emerging problems on the basis of mutual agreements and acceptable compromises. Today, Kazakhstan already has a 
solid international legal base in the formats of multilateral and bilateral cooperation, as well as in the framework of participation in international organizations.

The basis of the choice of foreign policy priorities was laid the geopolitical factor, i.e. taking into account the fact of Kazakhstan's location between two nuclear and economically developed powers - Russia and China. Moreover, such a factor as intracontinentality, i.e. lack of direct access to the sea by the republic. The unfavorable geographical location of the Republic of Kazakhstan as a landlocked country negatively affects its economic development. The vast majority of inland countries are less developed than countries with a sea coast. Free access to and from the sea is an important issue for countries that do not have such an exit, because their ability to use the sea to a certain extent depends on the coastal neighbors whose ports they are forced to use to communicate with the outside world.

Despite the adverse geographical factors listed above, an analysis of the foreign political activity of the Republic of Kazakhstan from the moment of gaining independence allows us to conclude that diplomatic means prevail in its implementation. Kazakhstan's lack of practical experience in foreign policy (since being a part of the USSR, our republic, however, like many others, was deprived of the opportunity to independently implement its foreign policy) did not affect the level and quality of foreign security. Properly designated priorities of the external security of the Republic of Kazakhstan during the formation of statehood contributed to the "painless" entry of our country into the world community as a full-fledged subject of international law.

The image and authority of the Republic of Kazakhstan, as well as the strengthening of its national security, were influenced by the decision of the country's leadership to renounce nuclear weapons. In May 1992, Kazakhstan signed the Lisbon Protocol and pledged to become a nuclearfree state. He was the first of the parties to the Lisbon Protocol to join the Treaty on the Non-Proliferation of Nuclear Weapons (NPT) with the status of a nuclear-free state. Later, a Memorandum was signed on providing our country with security guarantees from all nuclear powers (Tokayev 2004b: 22, 23).

It should be noted that Kazakhstan's contribution to the nuclear disarmament process was not limited to the closure of the Semipalatinsk nuclear test site and the signing of the Lisbon Protocol. In 2009, at the 64th session of the UN General Assembly,
Kazakhstan made a proposal to proclaim August 29 as the International Day against Nuclear Tests. It was on this day 19 years ago that ex-President N.A. Nazarbayev, by his decree, forever closed one of the largest nuclear test sites in the world. This idea received unanimous support, reflecting the deep concern of the international community regarding the dangers posed by such trials. This date was approved by the decision of the UN General Assembly on December 2, 2009 as "World Day on the renunciation of nuclear weapons" (Mansurov 2011: 317, 318).

This fact indicates a large-scale foreign policy initiative of the Republic of Kazakhstan in the development of global disarmament and the strengthening of external security.

This proves once again that the national security of the state is connected with foreign political activity and the activities of other subjects of international relations. States, entering into international legal relations, affect each other's external security. It is impossible to defend one's national interests without taking into account the interests of other subjects of international relations. Moreover, the process of ensuring the national security of the state is influenced by any political processes taking place in the world, therefore the state is forced to respond mobilely to any destabilizing factors that appear in the region or in the international community. In addition, the state, taking measures to ensure and strengthen its own security, indirectly takes part in ensuring local, regional and collective security, which are subsystems of the "vertical arrangement" of external security.

Assessing the role of external security in ensuring the national security of the state, it is necessary to emphasize that the security of each participating state is inseparably linked with the safety of all other participating countries. So, on the initiative of the First President of the Republic of Kazakhstan - the leader of the nation, the Conference on Interaction and Confidence Building Measures in Asia (CICA) was created and is functioning. It is no secret that the CICA was created as an Asian counterpart to the OSCE. There is a huge field for interaction here, since half of the twenty CICA members are either participants or Asian partners of the OSCE, which allows us to talk about the potential complementarity of these two organizations. In addition, the republic is a party to the treaty on the non-proliferation of nuclear weapons, the military-political bloc of the Collective Security Treaty Organization, the Shanghai Cooperation Organization (SCO), and is 
actively cooperating with NATO in the framework of the Partnership for Peace program.

EurAsEC, one of the most effective and promising integration associations, is a form of integration of sovereign states aimed at realizing the national interests of each participating country in order to strengthen stability and external security.

The EurAsEC, being the most effective integration structure in the post-Soviet space, created the logical prerequisite for the formation of the next stage of economic integration - the Customs Union (Kazakh President Nursultan Nazarbayev 2010: 518).

It can be argued that, in comparison with other integration structures on the territory of the former USSR, the Eurasian community is a successful integration entity that takes into account not only mutual benefits and prospects, but also the national interests of each participant.

The strategic program "Kazakhstan - 2030" contains a detailed analysis of the situation in the country at the moment, and it outlines the main "priority long-term goals," among which the first is to ensure external security: "To ensure the development of Kazakhstan as an independent sovereign state while maintaining complete territorial integrity "( www.akorda.kz).

The strategy provides, as the main measures to strengthen national security, the provision of a favorable external environment for internal political reforms, through the establishment of stable and friendly relations, primarily with neighboring states, as well as with the leading political and economic powers of the modern world. In addition, serious attention was paid to the development of cooperation with international institutions and forums, such as the UN, IMF, World Bank, Asian, European and Islamic development banks. The key to success of the republic's economic and political growth is economic cooperation and integration by providing diplomatic means of our country's access to foreign markets in order to profitably invest excess financial resources. Thus, it is clear that the main role in ensuring the national security of Kazakhstan was assigned to ensuring external security.

In addition, Part III "Key Directions for Kazakhstan's Development until 2020" of the Strategic Plan for the Development of the Republic of Kazakhstan until 2020 includes "International Relations and Foreign Policy", among which the following are highlighted: "Kazakhstan will continue to justify itself a course towards the prevention of an arms race, supporting the efforts of the international community in the field of nuclear disarmament and strengthening the regime of the Treaty on the NonProliferation of Nuclear Weapons. At the same time, opportunities will be maximally utilized within the framework of the Chairmanship of the Republic of Kazakhstan in authoritative international organizations (Organization for Security and Cooperation in Europe, Organization of the Islamic Conference, etc.) "( www.zakon.kz)

In the framework of ensuring external security, the Government defined "increasing the role and authority of Kazakhstan in the Muslim world", which is achieved through the tasks. So, this goal can be realized by activating the activities of the Republic of Kazakhstan in the activities of the OIC and by increasing the number of citizens of the Republic of Kazakhstan represented in the OIC bodies (oline.zakon.kz).

It must be emphasized that the intensification of relations between Kazakhstan and Muslim countries within the framework of the OIC meets the longterm interests of the republic. This is also defined in the Address of the President of the Republic of Kazakhstan N. Nazarbayev to the people of Kazakhstan, in which he noted the comprehensive development of cooperation with Islamic countries as one of the priorities of the foreign policy of the Republic of Kazakhstan (akorda.kz).

Thus, it can be noted that the principle of multivectorness, which involves "personal" cooperation with European states, the USA, China, Russia, the Middle East, and also the development of "collective" cooperation should be maintained at the basis of the external security of the Republic of Kazakhstan. in the framework of international organizations, such as the UN, CICA, OSCE, SCO, CIS, OIC, etc.

The continuation of the idea of pursuing a multi-vector policy was reflected in the Message of the President of the Republic of Kazakhstan to the people of Kazakhstan, who noted: "We will continue our balanced foreign policy, interacting not only with the West, but also with Asian states" (akorda.kz).

Thus, the external security of Kazakhstan not only ensures and protects national interests in international relations. It can be argued that with the same stubbornness, the Republic takes an active part in international events aimed at combating external threats in order to strengthen regional and international security (Baykenzheev 2016). 


\section{Conclusion}

National security can be differentiated depending on the location of the source of danger into two types: internal - activities within the state to ensure its stability; external - activities outside the state.

External security is characterized as the protection of the national interests of the Republic of Kazakhstan from threats posed from outside by other states (groups of states).

Since many processes and phenomena occurring in the country and in the world, it is difficult to limit the scope of the state, the areas of internal security and external security are interrelated, they complement each other or intersect. In the period of unstable internal development of the state, civil war, social conflicts, ensuring internal security becomes a priority. During wars, interstate clashes, conflicts, more attention is paid to ensuring external security. In the current globalization of all aspects of public life, when there are many threats to national security (terrorism, drug addiction, organized crime, the spread of various infectious diseases, epidemics, etc.), it is difficult to determine the boundaries between internal and external security.

In the field of ensuring the national security of the Republic of Kazakhstan, the main legislative act is the Law "On the National Security of the Republic of Kazakhstan" dated January 6, 2012, which defines the content and principles of ensuring the safety of man, citizen, society and the state, system, goals and directions for ensuring national security of the Republic of Kazakhstan. With regard to legislative consolidation of the external security of the Republic of Kazakhstan, when analyzing the current Law on National Security, in particular Article 4 "Types of National Security", the concept of external security is absent among other types of security. Although in the first special law adopted in 1998 and in force until 2012, the following definition was given to the type of security under consideration: "external security the state of protection of the national interests of the Republic of Kazakhstan from threats posed by foreign states, organizations and citizens."

In our opinion, the main threats to national security related to transnational phenomena, such as terrorism, extremism, drug trafficking and arms trafficking, remained outside the law. Also, the very geopolitical location of our republic strongly dictates to us to ensure and strengthen national security precisely through competent foreign policy activities of Kazakhstan. Thus, enhanced measures to counteract the above phenomena should be included in the category of priority tasks of national security of Kazakhstan at the present stage.

In this regard, we believe that it is necessary to supplement and expand the role and importance of foreign policy in ensuring national security at the legislative level by introducing amendments and additions to the law on national security.

We also offer the following definition of the state's external security: it is the protection of national interests, national values and lifestyles from external threats, as well as the ability and actions of the state to withstand these threats.

\section{References}

Baykenzheev A.S. Constitutional and legal framework for ensuring national security in the Republic of Kazakhstan. - Almaty, $2017 .-150 \mathrm{p}$.

Baykenzheev A.S. Theoretical and legal problems of ensuring national security in the Republic of Kazakhstan // Science and Life of Kazakhstan. - 2017. - No. 3. - p. 198-203

Baykenzheev A.S., Ibraeva A.S. To the question of improving the national legislation governing the fight against terrorism in the Republic of Kazakhstan // News of the National Academy of the Republic of Kazakhstan. - 2016.- No. 6. - p. 269-274.

Diplomatic Service of the Republic of Kazakhstan / Edited by K.Tokayev. - Almaty: Press House "Edelweiss", $2004 .-544$ p.

Kazakh President Nursultan Nazarbayev. The strategy of eternal friendship Kazakhstan-Russia. - Moscow: CPI «Russian Rarity», 2010. -538 p.

Mansurov T. Eurasia Project Nursultan Nazarbayev, accomplied in life. - Moscow: Real-Press, 2011 .- 320 p.

Message of the President of the Republic of Kazakhstan N.A. Nazarbayev to the people of Kazakhstan. March, 2006. "Strategy of occurrence of Kazakhstan in number of 50 most competitive countries of the world Kazakhstan on a threshold of new breakthrough forward in the development" / akorda.kz/

Message of the President of the Republic of Kazakhstan N.A. Nazarbayev to the people of Kazakhstan. 01/27/2012. "Social and economic modernization - the main vector of development of Kazakhstan" / akorda.kz/

Message of the President of the Republic of Kazakhstan N.A. Nazarbayev to the people of Kazakhstan. 1997 "Kazakhstan2030. Prosperity, safety and improvement of welfare of all Kazakhstan citizens" / www.akorda.kz/ 
The decree of the President of the Republic of Kazakhstan from February 1, 2010 of No. 922 "About the Strategic development plan of the Republic of Kazakhstan till 2020" / www.zakon.kz

The resolution of the government of the Republic of Kazakhstan from December 23, 2008 of No. 1212 "About the Strategic plan of the Ministry of Foreign Affairs of the Republic of Kazakhstan for 2009-2011" (with changes as of 12/29/2009) / online.zakon.kz/

Tokayev K.K. Main aspects of process of formation and development of foreign policy of the Republic of Kazakhstan // Actual problems of foreign policy of Kazakhstan: collection of articles. - Moscow: IPTs "Russian Rarity", 1998. - 413 p.

The Law of the Republic of Kazakhstan "On National Security of the Republic of Kazakhstan” dated June 26, 1998 https:// online.zakon.kz/document

The Law of the Republic of Kazakhstan "On the National Security of the Republic of Kazakhstan" dated January 6, 2012 (as amended on December 28, 2018) // https://online.zakon.kz/document

The Constitution of the Republic of Kazakhstan. Adopted on August 30, 1995.// https://online.zakon.kz/document 